\title{
Analysis of water quality in Maninjau Lake, West Sumatera, Indonesia using phytoplankton
}

\author{
Muhammad Arif Salsabil ${ }^{1}$, Astri Rinanti ${ }^{1}$, and Melati Ferianita Fachrul ${ }^{1 *}$ \\ ${ }^{1}$ Universitas Trisakti, Department of Environmental Engineering, Faculty of Landscape Architecture and Environmental Technology, \\ Jakarta, Indonesia
}

\begin{abstract}
This research aimed to analyze the water quality of Maninjau Lake $\left(0^{\circ} 19^{\prime} \mathrm{N} 100^{\circ} 12^{\prime} \mathrm{E}, 0,317^{\circ} \mathrm{S}\right.$ $\left.100,2^{\circ} \mathrm{E}\right)$, West Sumatera, Indonesia by phytoplankton as bioindicator of water quality. The quality of water was determined by identified the phytoplankton. Analyzed phytoplankton as bioindicator with Diversity Index (H'), Evenness Index (E) and Dominance Index (D). The abundance of phytoplankton ranged 273378 cell/liter, consists of three division which are Cyanophyta, Chrysophyta, and Chlorophyta. The average value of Diversity Index (H') is 3.52 show that the waters classified as moderate, or indicating half-polluted waters. The average value of Evenness Index (E) is 0.92 indicating that the evenness of species is medium. The average value of Dominance Index (C) is 0.12 , meaning there is not any phytoplankton dominance in the waters. Maninjau Lake is slightly polluted caused by organic and inorganic contaminants from many activities surrounding especially household and fish breeding activities. The research show that Maninjau Lake is in oligotrophic state or nutrient-deficient waters.
\end{abstract}

\section{Introduction}

Waste disposal activity, both domestic and non-domestic waste, which discharged directly into waters could cause decreasing in water quality level due to changes in water quality parameters in the water. Maninjau Lake is a volcanic lake with area of approximately $99.5 \mathrm{Km}^{2}$ located in Tanjung Raya Sub-District, Agam District, West Sumatera. Maninjau Lake mainly used as water reservoir, fish breeding area, recreation area, and hydroelectric power plants. Around Maninjau Lake, there are houses, hotels, and restaurant. Activities around Maninjau Lake could cause of environmental pollution and the changing in water quality. Maninjau lake also contain high level of phosphate which also affect the water quality of Maninjau Lake.

The water quality could be determined by physical, chemical and biological parameters. Bioindicator is a species or a certain community, with its existence could give information of the physical and chemical of the environment in a certain place [1]. Phytoplankton has a different sensitivity and tolerance to pollutants, so it can be an indicator in water environment quality. In addition, the sensitivity of phytoplankton to changes in water conditions is a strong reason to make phytoplankton as a bioindicator of water. By knowing the structure of phytoplankton community in Maninjau Lake, it can also be obtained the value of Abundance of phytoplankton, Diversity Index, Evenness Index, and Dominance Index, which can be used as a reference to analyze the pollution level in Lake Maninjau. The abundance of phytoplankton in the waters could describe the water fertility rate.
In a trophic level, phytoplankton occupied the bottom position as the main food source for the aquatic animals. It could also be said that waters with phytoplankton's high primary productivity will have a great biological resources [2]. Based on that it is necessary to do the research using phytoplankton as bio indicator.

\section{Research methodology}

This research was conducted from May to July 2017 at Maninjau Lake, Tanjung Raya Sub District, Agam District, West Sumatera, Indonesia. Sampling of phytoplankton was conducted in three periods at 11 sampling point based on the activities around Maninjau Lake using the plankton net with mesh of $25 \mathrm{~mm}$ and identified in Biological Laboratory of STKIP PGRI Padang. The preservation of phytoplankton using Formalin 4\%, $\mathrm{MgCO} 3$, Acetone.

\subsection{The abundance of phytoplankton}

The abundance of phytoplankton was done by counting the cell of phytoplankton with sedwick rafter counting cell with cell/liter [3]. To know the abundance of phytoplankton in cell/liter, used formula is as follows:

$$
N=\frac{X}{Y} \times \frac{1}{V} \times Z
$$

$\mathrm{N}=$ Phytoplankton abundance (cell/liter), $\mathrm{X}=$ The volume of filtered water $(250 \mathrm{ml}), \mathrm{Y}=$ Volume $1 \mathrm{drop}$

\footnotetext{
* Corresponding author: melati@faltl.trisakti.ac.id
} 
$(0,05 \mathrm{ml}), \mathrm{V}=$ Water volume (100 liter), $\mathrm{Z}=$ Total of found individual (cell)

\subsection{Diversity index $\left(\mathrm{H}^{\prime}\right)$ of phytoplankton}

This analyisis was used to know the diversity of water biota. If the diversity rate is high, the community of phytoplankton in the water is not dominated by one or two species. The formula used for this index is ShannonWiener formula [4].

$$
H^{s}=-\Sigma P i \log 2 P i, P i=\frac{n i}{N}
$$

$\mathrm{H}^{\prime}=$ Diversity index, $\mathrm{Ni}=$ total indivdual genes no-I, $\mathrm{N}$ $=$ Total individual of all genera.

\subsection{The evenness index (E) of phytoplankton}

The evenness index is used to determined wether the species is evenly distributed or not. If the index rate is high, then the species is evenly distributed or is not so much different from one another. To determine the Evenness Index of phytoplankton, we can compare the Evenness Index with the maximum value.

$$
E=\frac{H}{H^{s} \text { maks }}
$$

$\mathrm{E}=$ Evenness index, $\mathrm{H}=$ Diversity index, $\mathrm{H}^{\prime} \max =\mathrm{Log}$

\subsection{The dominance index (C) of phytoplankto}

Dominance index is to determine wheter or not the species predominates others in water [5]. To know Dominance Index value used the formula as follows.

$$
C=\sum_{i=0}^{n}\left[\frac{n i}{N}\right]^{2}
$$

$\mathrm{C}=$ Dominance index, $\mathrm{Ni}=$ Total individual gene no-I, $\mathrm{N}=$ Total individual, $\mathrm{N}=$ Total genera (kind)

\section{Result and discussion}

\subsection{The abundance of phytoplankton in Maninjau Lake}

The abundance of phytoplankton is related to the fertility of a water. Abundance of phytoplankton influenced by abiotic factor on them is dissolved oxygen content (DO). The watershed DO content that can be tolerared by aquatic organisms especially phytoplankton is not less than $5 \mathrm{mg} / \mathrm{L}$ [6]. The highest abundance of phytoplankton was found at point 8 on May (Fig. 1), which was 272.5 cells/litter, while the lowest abundance of phytoplankton was present at point 5 , with. only 77.5 cells/litter.

$2 \mathrm{Pi}$

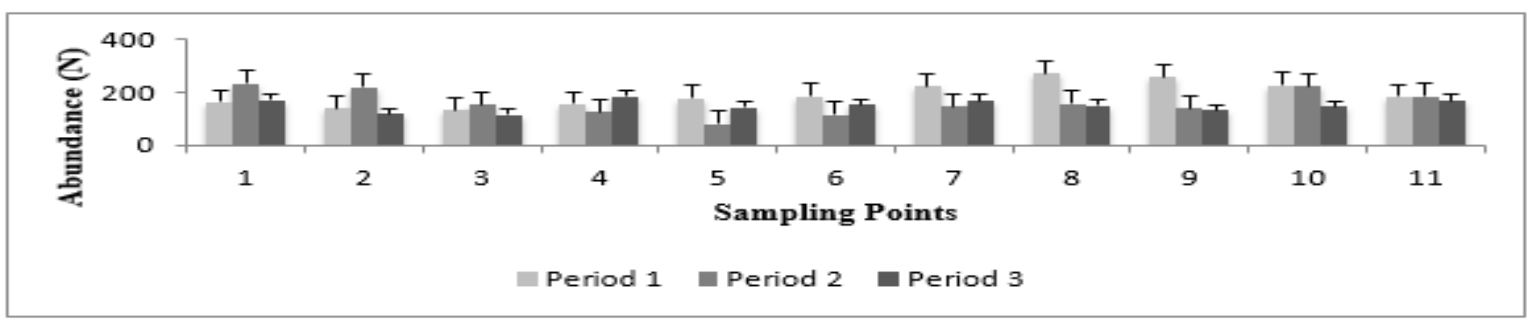

Fig. 1. Maninjau Lake abundance index.

The abundance of phytoplankton in Maninjau Lake, which is less than 2000 cells/liter between $1638-2110$ cells/liter indicates that Maninjau Lake is in oligotrophic status or nutrient-deficient waters. Associated with the level of water fertility, this condition is influenced by nutrients that enter into the water. Nutrients come from organic matter in waters transformed by microorganisms. Organic materials include carbohydrates, fats and proteins. The source of organic matter in Lake Maninjau comes from the activity around the lake. From the nutrient state seen that the nutrients utilized by phytoplankton in Lake Maninjau are in low condition marked by low abundance rate of phytoplankton as seen in Fig 1.

Total abundance of phytoplankton obtained in this analysis is different compared to previous research in Maninjau Lake [7]. The total abundance value was around 17.038-21.565 cells/liter. The high abundance value was due to sampling points was near fish breeding activity, and by the time of sampling, fishes was still in the feeding stage while in the present research, it was a fish harvest time, so there are a decreasing amount of total organic material. Nutrients in waters really can affect the total abundance of phytoplankton like from Santragachi Lake in India which has a high nutrient in waters so it has a high abundance of phytoplankton around 27.494-40.658 cells/liter [8].

\subsection{Diversity index ( $\left.\mathrm{H}^{\prime}\right)$ of phytoplankton}

The diversity index is a relation of three factors: the variety of species, the number of individuals in each species, and the total individuals in the community. A community is said to have a high diversity if the community is composed by many species with an abundance of identical or almost identical species. The following is the index value of phytoplankton diversity in Lake Maninjau. 


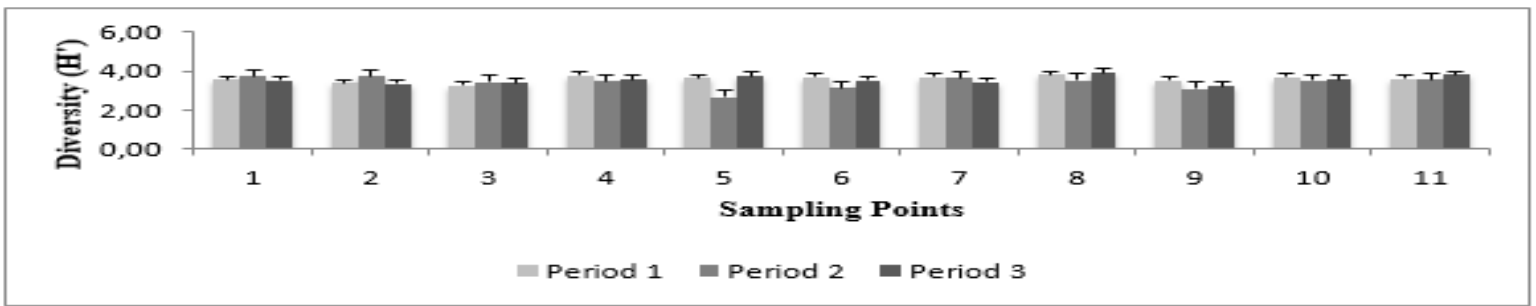

Fig. 2. Maninjau Lake diversity index.

The Diversity Index in Lake Maninjau in the three periods ranges from 2.67 to 3.92 as seen in Fig 2 . Overall, it can be seen that the diversity of Lake Maninjau has a moderate-to-high level of diversity and when compared to water quality criteria based on Shannon Wiener's diversity index with an average value of 3.52 diversity, Lake Maninjau's waters fall into very lightly polluted criteria.

The value of Diversity Index in this research is a little bit high compared to previous research that has been done in Maninjau Lake which is around 1.96-2.88 [9]. It can be concluded that the total diversity in Maninjau Lake is improving but still has a moderate level of diversity.

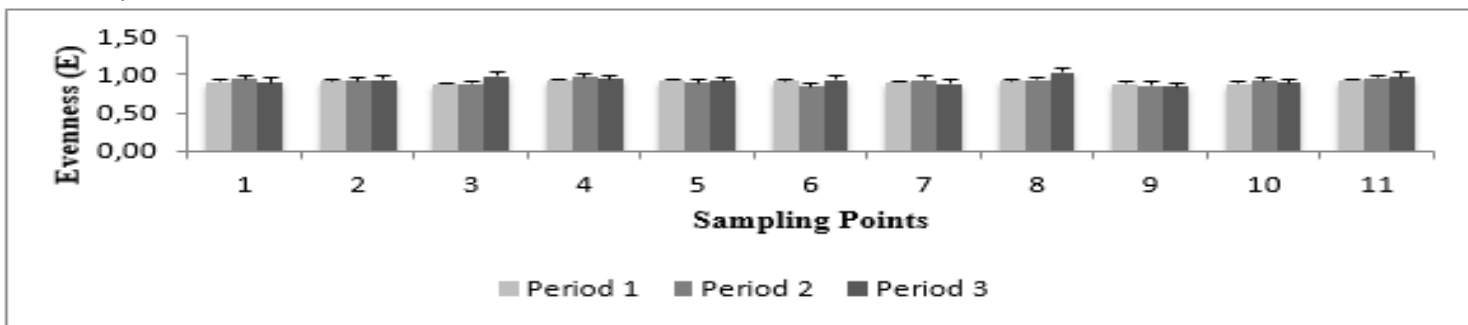

Fig. 3. Maninjau Lake evenness index.

Based on fig. 3 above it can be seen that the value of phytoplankton evennes index in Maninjau Lake in the sampling period ranged from 0.84 to 1.03 which is close to 1 , hence means that the evennes between the species is relatively even and the difference is not so conspicuous as seen in Fig 4. The value of this evennes index has properties directly proportional to the value of the diversity index $\left(\mathrm{H}^{\prime}\right)$. As the value of evennes index approaches 1 , the value of the diversity index will be high. The evennes index (E) close to 1 is influenced by ecosystem conditions suitable for the growth of phytoplankton, so that the phytoplankton distribution pattern is relatively evenly distributed.

It could also be proofed from previous research in Maninjau Lake that the Evenness Index is improving with the value around $0.65-0.81$ and its species is considered relatively even.

\subsection{Evenness index (E) of phytoplankton}

The index value of phytoplankton evennes ranges from 0 to 1 , when the evennes index is related to the condition of the community and its environment, the evennes index approaching 0 , tends to indicate an unstable community. In contrast, a high index of evennes is a reflection of the community in a stable state, the individual interconnected species is relatively similar. The value of evennes index (E) of phytoplankton at three periods in Lake Maninjau is shown in the table below.

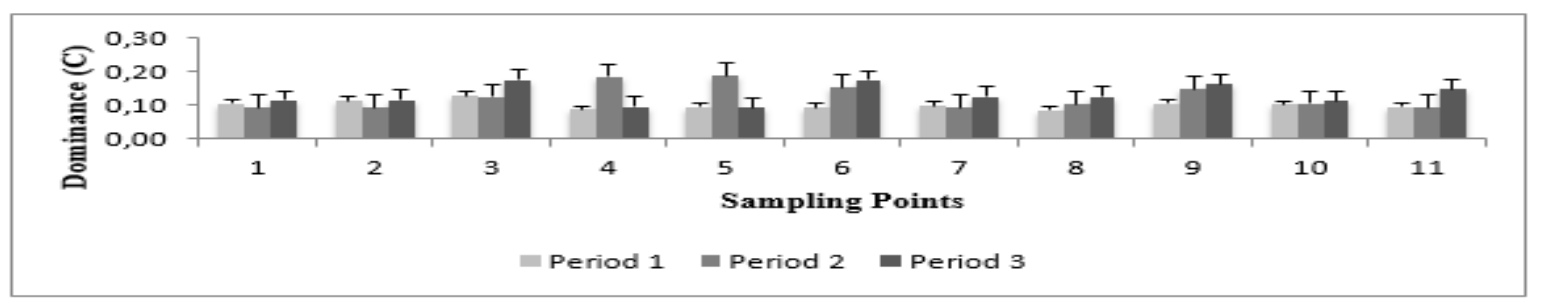

Fig. 4. Maninjau Lake dominance index.

\footnotetext{
Corresponding author: melati@faltl.trisakti.ac.id
} 
The index value of phytoplankton dominance ranged from 0.09 to 0.19 as seen in Fig 4. In the sampling period in Lake Maninjau, almost the overall value of the dominant index is close to zero. It shows that phytoplankton can grow and develop optimally so that no species dominate other species.

If there are enough nutrients in the waters, then phytoplankton can grow optimally just like in some lake like Santragachi Lake in India with Dominance Index of 0.108-0.14 and Bulakan Lake in Tangerang, Indonesia with the value of Dominance Index around 0.61-0.79.

\section{Conclusions}

The Abundance of phytoplankton in Maninjau Lake ranged from $1638-2110$ cells/liter. The structure of the phytoplankton community consists of divisions of Cyanophyta, Chlorophyta, and Chrysophyta. The Diversity Index value phytoplankton ranged from 2.67 to 3.92, the Evennes Index (E) ranged from 0.84 to 1.03 , and the Dominance Index (C) ranged from 0.09 to 0.19 . These research show that Maninjau Lake is in oligotrophic state or nutrient-deficient waters.

\section{References}

1. Bellinger and Sigee. Freshwater Algae: Identification and Use as Bioindicators. (2010)

2. Radiarta, I.N. Hubungan antara distribusi fitoplankton dengan kualitas perairan di Selat Alas, Kabupaten Sumbawa, Nusa Tenggara Bara, (2013)

3. American Public Health Association (APHA). Standard Methods of the Examination of Water and Waste Water. 19 $9^{\text {th }}$ ed. Pp. 1015 (AWWA. WEF. NEW York. 1995)

4. Basmi, J. Planktologi: Plankton sebagai Bioindikator Kualitas Perairan. (Fakultas Perikanan dan Ilmu Kelautan. Institut Pertanian Bogor. 1999)

5. Odum, E. P. Dasar-dasar Ekologi. Alih Bahasa : Samingan, T dan B. Srigandono. Edisi Ketiga 824 hlm. (Universitas Gadjah Mada Press, Yogyakarta, 1998)

6. Ramadhania, Fitoplankton Sebagai Bioindikator Saprobitas perairan di situ bulakan kota tangerang. Al-Kauniyah j biologi Vol. 8 No. 22015. Universitas Islam Negeri Syarif Hidayatullah, Jakarta, (2015)

7. Ulfa. Jenis dan Kelimpahan Fitoplankton di Danau Maninjau Kecamatan Tanjung Raya Kabupaten Agam Provinsi Sumatera Barat. (2017)

8. Ghosh, Diversity and Seasonal Variation of Phytoplankton Community in the Santragachi Lake, (West Bengal, India. 2012)

9. Merina, Komposisi dan Struktur Komunitas Fitoplankton di Danau Maninjau Sumatera Barat. (2014)

\footnotetext{
${ }^{*}$ Corresponding author: melati@faltl.trisakti.ac.id
} 